\title{
Other picture boards in Van Diemen's Land: The recovery of lost illustrations of frontier violence and relationships
}

\section{Nicholas Dean Brodie and Kristyn Harman}

Art history is replete with works whose prior existence is affirmed only by text, most commonly through titles and descriptions in catalogues, but also by passing mentions in other sources. A significant Australian colonial illustration of this phenomenon of textually surviving lost art concerns 'Several Paintings on Panel', described in detail by a colonial witness, which depict scenes intended to convey government messages to Indigenous Tasmanians during the Vandemonian War. These descriptions do not match the better known and frequently reproduced Tasmanian Picture Boards, typified in Figure 1, which survive in several archives around the world and have been the subject of considerable study and commentary. ${ }^{1}$ Their iconographical recovery is, we argue, an important correction to the imagery of frontier relations in 1820s and 1830s Van Diemen's Land specifically and colonial Australia more generally.

\footnotetext{
1 These boards are held within the collections of the Tasmanian Museum and Art Gallery, the Queen Victoria Museum and Art Gallery, the National Museum of Australia, the Mitchell Library, the Museum of Victoria, the Cambridge Museum of Archaeology and Anthropology, and the Peabody Museum at Harvard University. Carroll 2014: 75-76, 78, 81, 83 .
} 


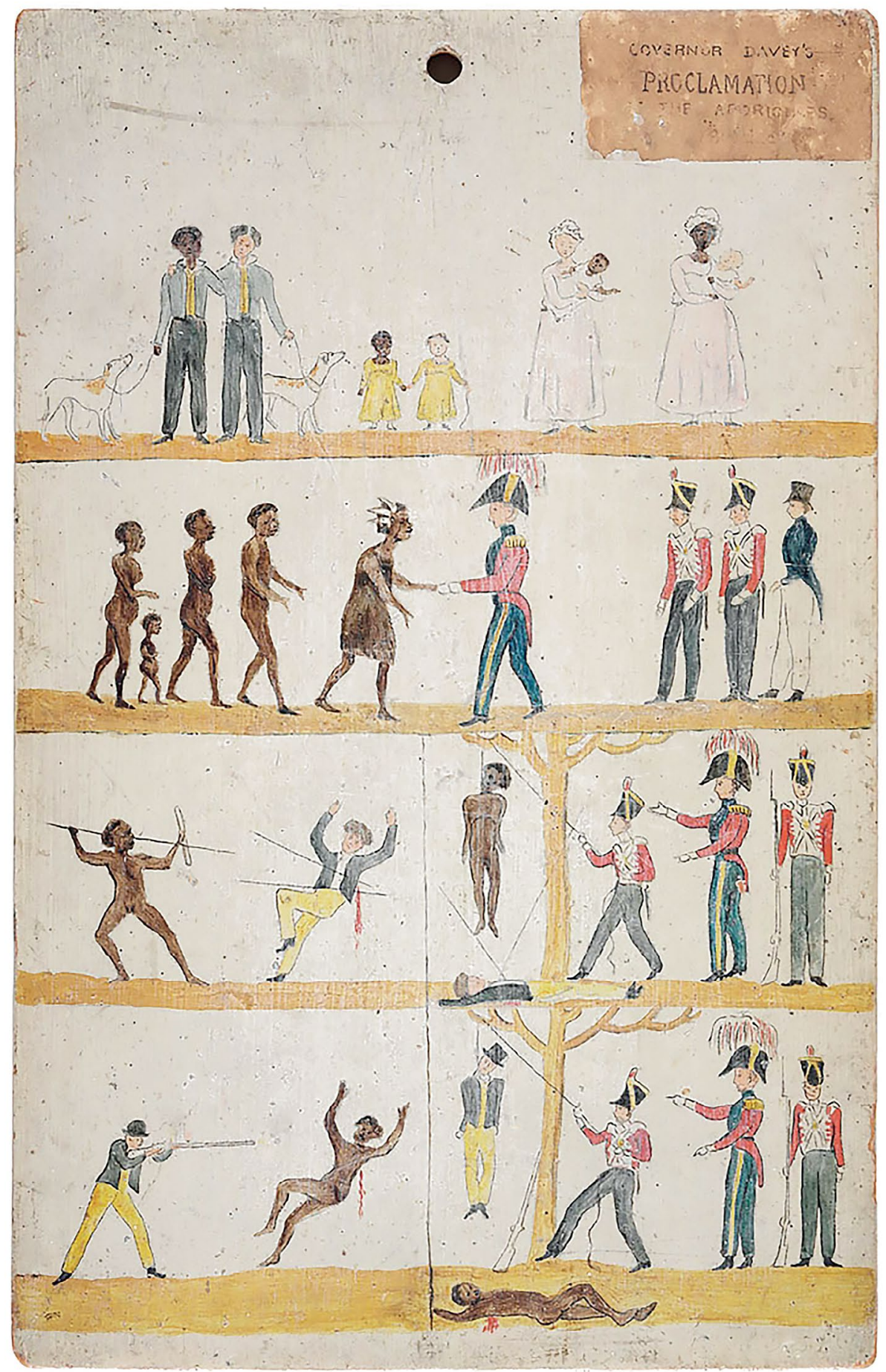

Figure 1: Tasmanian Picture Board A, c. 1830. An example of the surviving boards. Source: Mitchell Library, State Library of New South Wales. 
Accounts contemporary with the original use of imagery to communicate with Indigenous Tasmanians are few and relatively terse. The clearest descriptors of government action survive from newspaper reports in the Colonial Times of Hobart. The editor of that paper wrote on 5 March 1830 of having been informed that the Government have [sic] given directions for the painting of a large number of pictures to be placed in the bush for the contemplation of the Aboriginal Inhabitants. ${ }^{2}$ These pictures were then briefly described in terms reminiscent of the well-known surviving boards. They were:

said to be representations of the attacks made by the black upon the white population, and in the back ground is to be seen a gallows with a black suspended; and, also, the same consequence to the white man, whom in the other picture is represented as the aggressor. ${ }^{3}$

Ten months later, the Colonial Times again referred somewhat sarcastically to this 'most ingenious plan' concerning a 'hundred pictures' supposedly (and seemingly meant ironically) 'painted, by an eminent artist in Hobart Town', which depicted 'black-killing whites, and white-killing blacks'. ${ }^{4}$ The editor had 'lately seen these productions', which were intended to be 'placed in different parts of the bush', suggesting their temporal proximity to these reports.

Curiously, however, even before these newspaper reports, it appears that such boards were already in use. Mrs A. Prinsep, a visitor to Van Diemen's Land in January 1830 and wife of a prospective settler, penned and then published a series of letters of her journey, which included a rumination on the state of affairs between the colonists and the Indigenous Tasmanians:

During the first years of the settlement, these poor naked creatures lived in great harmony with us, came without fear into the white man's house, and soon felt the value of a blanket and other little trifles. In course of time, however, these articles became naturally so coveted by them, that they commenced thieving; this was resisted, and one or two imprudent timid stock-keepers fired and killed some of the natives. Deadly hatred was in consequence avowed against the whites, which not even all the pictures of explanation our friend F- has hung up in the woods, depicting the governor punishing the white man for firing at the black, can lessen. Great pains have been taken with those that are caught, to civilize and educate them but, excepting learning a few English sentences, it was to little purpose, as they invariably ran back to the woods when an opportunity offered. ${ }^{5}$

\footnotetext{
Colonial Times, 5 March 1830: 2.

Colonial Times, 5 March 1830: 2.

Colonial Times, 14 January 1831: 2.

Prinsep 1833: 78-79 (emphasis added).
} 
Describing these boards in January 1830 as being 'hung up' in the past tense, and textually situated amid an account of her own journey to the town of New Norfolk, where she perhaps observed such images in situ, Mrs Prinsep complicates the established timelines scholars have drawn from the Colonial Times, but also affirms the key personality increasingly associated with the surviving boards. At a dinner of the Van Diemen's Land Society in January 1830, Mr Prinsep was reported toasting with 'his Friend, Mr Frankland' a plan to inquire into 'the character and habits of the aborigines of Van Diemen's Land'. 6 Surveyor General George Frankland, mostly likely 'our friend F-' was certainly one of the more vocal 'doves', or peacemakers, advocating relative restraint towards Aboriginal people during the Vandemonian War. ${ }^{7}$

A year earlier, in February 1829, Frankland had advocated using pictures to communicate with Indigenous Tasmanians, telling Lieutenant Governor Arthur that he had:

sketched a series of groups of figures, in which I have endeavoured to represent in a manner as simple and well adapted to their supposed ideas, as possible, the actual state of things /or rather the origin of the present state / and the desired termination of Hostility. ${ }^{8}$

Frankland proposed that the pictures 'be multiplied' on 'more durable materials', and then 'fastened to trees in those remote situations where the Natives are most likely to see them'. ' Because of this letter, the use of boards in 1830 has generally become accepted as Frankland's initiative, and the surviving designs are by association connected with him. ${ }^{10}$ Certainly Mrs Prinsep seems to have accepted the association.

Yet, late in 1830, another colonial newspaper described Frankland giving an image to Eumarrah, a tribal chief accompanying a colonial mission, which does not match the surviving imagery:

Before the departure of Numarrow [Eumarrah], Mr. Frankland presented him with a little sketch, executed with much spirit, of the consequences of the Aborigines adopting a peaceable demeanour, or of continuing their present murderous and predatory habits. In one part of the sketch, the soldiery were represented firing upon a tribe of the Blacks, who were falling from the effects of the attack. On the other part were seen, another tribe, decently clad, receiving food for themselves and families. ${ }^{11}$

6 Hobart Town Courier, 23 January 1830: 4.

7 Brodie 2017b: 128, 131-32, 291.

8 Frankland to Arthur, 4 February 1829, Tasmanian Archives and Heritage Office, LSD17/1: 23.

9 Frankland to Arthur, 4 February 1829, Tasmanian Archives and Heritage Office, LSD17/1: 23.

10 Edmonds 2011.

11 Tasmanian and Austral-Asiatic Review, 26 November 1830: 783. See also Bonwick 1870: 84 for a slightly mistranscribed version. 
These described images do not conform to those on the known surviving boards and, upon closer examination, nor does the logic of Frankland's 1829 letter. There were, it seems, other images with other messages. While the surviving boards have been subject to considerable scholarly discussion and varying interpretation, this has been predicated on a generalised context derived from the above-cited sources (excepting Mrs Prinsep), which has conflated what are clearly distinct iconographical sequences. Moreover, while some historians have acknowledged the likely existence of other iconographical traditions, to date no extensive discussion of this has been forthcoming. We hope to fill this gap by recovering and investigating the alternative iconography represented in a remarkable source. ${ }^{12}$

'Several Paintings on Panel (a rather perishable material for their intended use) were executed' during the Vandemonian War, according to the currently unknown author of 'The Aboriginal Natives of Van Diemen[']s Land', a first-hand account of colonial Van Diemen's Land, surviving in two distinct copies. A description of several 'compartments' within these images followed this comment, detailing a set of imagery unlike the surviving boards, but similar in tone, content and purpose to Frankland's sketches of 1829 (detailed to Arthur) and 1830 (given to Eumarrah).

The text of 'The Aboriginal Natives of Van Diemen[']s Land' survived into modern times in two variants. One original manuscript copy is held in the Allport Library at the State Library of Tasmania in Hobart and, for present purposes, will be referred to as the 'Allport MS'. ${ }^{13}$ The other copy of the text is currently known only in transcription. In 1926, Tasmanian antiquarian and surgeon William Crowther described, transcribed and published a manuscript supposedly originating from 'among the papers of the Rev. R. Knopwood', although apparently not in his distinct handwriting. ${ }^{14}$ Because Crowther acquired the manuscript from the collection of the colonial photographer James Beattie, we have designated it the 'Beattie MS'.

Borrowing from the manuscript analysis techniques deployed for medieval studies, we are confident that the Beattie MS and the Allport MS are not the same document, even though they reflect the same general text. The Allport MS has additional elements not transcribed from the Beattie MS. By Crowther's account, the Beattie MS 'ceases' at a point before the text of the Allport MS does. Close reading suggests

12 Independently of the project presented here, Tasmanian Aboriginal artist and writer Dr Julie Gough also visually reconstructed these images after recording the source manuscript in the Allport Library and Museum of Fine Arts on 28 July 2013. Her results are as yet unpublished, but were presented at a public talk at the Allport Library and Museum on 6 August 2015. The authors are grateful to the reviewer who brought this parallel research to their attention in July 2017, and to Julie Gough for allowing us to then see her images. Our commissioned reproductions were presented at the Australian Historical Association conference, Sydney, 9 July 2015.

13 'Allport MS', Tasmanian Archives and Heritage Office, Allport Library and Museum Manuscripts, L8 Store, Box 2, Folder 1.

14 Crowther 1926. 
that the shorter Beattie MS was probably a cleaner copy of the heavily corrected Allport MS. Crowther's transcript of the Beattie MS had additional grammatical marks (mostly commas), some differing capitalisation, some shifts between singular and plural forms of words, a handful of other minor syntax shifts (for instance concerning word ordering within sentences) and the expansion of ampersands into the word 'and', by which points it differs in multiple respects from the Allport MS. There are, moreover, some word differences, and in one section the tense is different, having been past tense in the Allport MS and present tense in Crowther's transcript. The Allport MS edits generally share corrected rather than redacted text with the Beattie MS, furthering the impression that the Beattie MS is a cleaner copy of the Allport MS.

This text can be broadly divided into two sections, the first providing ethnographic reminiscences about Indigenous Tasmanians, and the second ruminating on government policy during Arthur's administration. It is the second part of the text with which we are mainly concerned, and here the Allport MS offers material later excluded from the clean copy. Generally, the account is hostile to Arthur's government. The writer noted that Indigenous Tasmanians frequented Hobart in 'the earlier Period of Col[one]l Arthur[']s Government', and laments they were not captured then. Referring to 'A second Plan of Operations', with parties in lines 'traversing the country', the writer alluded to the General Movement (widely known as the 'Black Line') of late 1830. Composition therefore postdates this event. The writer then mentioned 'the Experiment of Conciliation', obliquely referring to the 'friendly missions' of the early to mid-1830s. This entire section is missing from the Beattie MS.

Following this, the writer described 'Several Paintings of Panel ... about Eighteen Inches Square' in both versions of the text. These paintings were 'divided into compartments each of which represented a series of Actions admonitory to the Natives of the course intended by the Government to be pursued in future towards them'. The text details the scenes depicted on two such boards, which will be addressed shortly. From here the writer referred to 'A Proclamation [that] was issued by which the natives were incorporated with the other British subjects in the Island, endowed with all their rights to the Protection of the Laws $\&$ also made liable to the Penalties incurred by their Violation'. Describing contemporary discussion of the problem of communicating with Aboriginal people, the writer noted a contemporary suggestion that 'the Bell man should be sent through the Bush'. The town crier apparently successfully argued against this idea. Finally, it was proposed to effect 'the capture of one of the Aborigines[,] his Instruction in the general Principles of Constitutional Law \& his subsequent dismissal to his Countrymen in order to impart to them in particular the matter [etc]'. Both manuscripts terminate in this section, the Beattie MS mid-sentence, and the Allport MS at the sentence's end. 
Mentions of Arthur, Chief Justice John Pedder, and allusions to the 'Black Line' and 'friendly missions' seem to situate the material covered in the text to the late 1820 s and early 1830s. Dating the manuscript itself is less straightforward. Crowther suggested that comments about Indigenous Tasmanians as 'now nearly extinct' would seem to place the writing of the text before the extinction discourse of the 1870s. ${ }^{15}$ We would go further, suggesting that the consistent use of the term 'Van Diemen's Land' probably indicates it was composed before 1856 when Van Diemen's Land was officially renamed Tasmania. According to Crowther, the Beattie MS was supposedly found 'among the papers of the Rev. R. Knopwood after his death' in 1838. This would indicate that the manuscripts were extant in the late 1830s, but some allowance must be made for the obvious gap between Knopwood's death in 1838 and Beattie's later collecting (Beattie was not born until 1859). The manuscript may well have formed part of Knopwood's papers, but could have been added to that collection at a subsequent date prior to being acquired by Beattie.

Certainly the style of the composition is consistent with other Vandemonian/ Tasmanian works from the middle decades of the nineteenth century such as Jorgen Jorgenson's manuscript about the Aborigines, seemingly intended as a book for the London market, and R.H. Davies's 'On the Aborigines of Van Diemen's Land' published in 1846, similarly aimed at a British audience. ${ }^{16}$ It is possible that the Allport and Beattie MSS reflect a text being prepared for publication in a similar way at a broadly similar time.

Situated within an early memorialising or chronicling tradition, this manuscript offers a reflective take on the then recent past, as well as a first-hand account. The 'Paintings on Panel' described by the writer 'were affixed to trees in distant parts of the Island', and were approximately twice as large as those boards that are currently known to have survived into the present. While described to illustrate colonial failures to effectively communicate with Indigenous Tasmanians, textually and narratively situated with other communicative attempts, this mocking description remains the most detailed surviving near-contemporary account of pictorial communication attempts with Indigenous Tasmanians. Strikingly different from the series depicted on the surviving boards, unfortunately the clarity of the text is somewhat haphazard. Yet, it is clear that the writer has described two separate boards and their constituent compartments that, we argue, likely reflect Frankland's original conception of 'the actual state of things /or rather the origin of the present state / and the desired termination of Hostility'.

15 Allport MS: 1; Crowther 1926: 165.

16 Plomley 1991; Davies 1846, reprinted in Hobart Town Courier, 7 March 1846: 4. 
For ease of discussion, we have adopted the convention of identifying picture board designs by sequence of scholarly discovery. Board A, as shown in Figure 1, reflects the commonly known version that survives in several copies. Boards B and $\mathrm{C}$ are those described in the Beattie and Allport MSS. Artistic impressions of Boards B and $\mathrm{C}$, based on the textual descriptions and borrowing styling from the surviving boards, are shown in Figures 2 and 3. These reconstructions were undertaken for the authors by Melbourne-based Tasmanian author, artist and illustrator Simon Barnard, who developed the style in consultation with the authors and through reference to the well-known imagery of Board A. Using a high-quality print of an exemplar of Board A from Cambridge in England, Barnard developed his version of the 'lost' boards, and then digitally aged his finished work 'to create the impression of 19 th century patina. ${ }^{17}$

In Board $\mathrm{B}$ there are six scenes. ${ }^{18}$ In the first, Indigenous Tasmanians 'were represented attacking an unfortunate Settlers House, reducing it to ashes \& placing him in a rather unsettled situation'. In the second, 'a terrified wight, his wig departing in one direction $\&$ his hat in another in the rapidity of his flight was depicted pursued by them'. This figure was 'rescued by an ambuscade of Soldiers' in the third compartment where 'a well directed discharge checked the advance of the Enemy'. The fourth had 'some of the Delinquents', presumably meaning Indigenous Tasmanian aggressors, 'in chains $\&$ the deadly grip of the Constable'. In the fifth compartment, Indigenous Tasmanians were in 'the Courts of Law and Hobart Town' with their 'trial in progress', where one of the figures resembled 'Chief Justice Pedder'. Finally, 'The subject of the sixth \& final was an Experiment on that abstruse subject of natural Philosophy, the Oscillation of the Pendulum, the native a Native being the wight $\&$ a well known Personage whose name was Dogherty, that of the Practitioner. ${ }^{19}$ This last part was a convoluted description of a hanging. ${ }^{20}$ The narrative sequence clearly articulated that the British responded to Indigenous Tasmanian attacks on colonial settlers with overwhelming force. As illustrated in The Vandemonian War, this was precisely the state of affairs under Arthur's regime in early 1829 , constituting what Frankland likely understood as 'the actual state of things. ${ }^{21}$ Board B was an explanation of, and perhaps justification for, the use of military force.

17 Barnard pers. comm. to Harman, 24 March 2015. The authors acknowledge funding received from the Centre for Colonialism and Its Aftermath to remunerate the artist.

18 Annotations and corrections to Allport MS show the writer getting a little confused with their enumeration. What follows is an amended version to correctly reflect the sequences described.

19 Part of this is unique to the Allport MS.

20 A John Dogherty was employed in Hobart as hangman by the mid-1830s. He is referred to as 'the common hangman' by the True Colonist, 6 November 1835: 2, and can be identified in many newspaper reports of executions about that time.

21 Brodie 2017b: 37-70. 


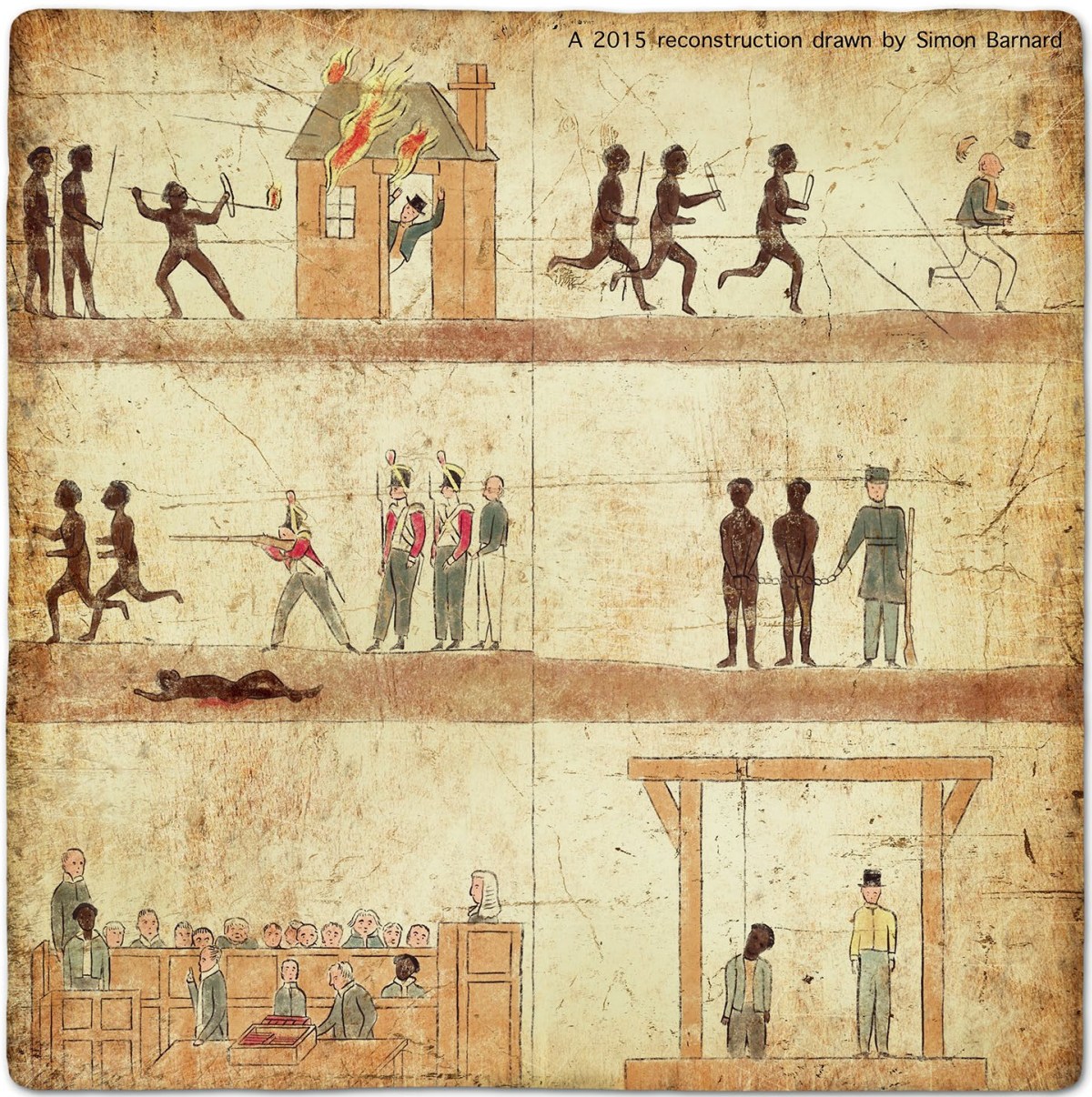

Figure 2: Board B, 2015. A reconstruction by Simon Barnard based on manuscript description.

Source: @ Nicholas Dean Brodie and Kristyn Harman.

Board C reflected the aspiration of 'wanting to encourage them in peace $\&$ submission', Frankland's 'desired termination of Hostility'. Its precise sequence is less clearly enumerated, but this design seems to have included at least four panels, starting with 'a Settler receiving from a Native a Kangaroo, whom he rewarded by a Portion of Damper'. It continued to articulate the picture with the subsequent three compartmentalised images:

[2nd] Again was seen the Governor in Regimentals, surrounded by a number of the Aborigines \& patting on the head in the most condescending manner a Pickaninny or infant Child. [3rd] Next appeared a Minister of the Church expounding to his dusky Audience the truths of Christianity to the evident astonishment $\&$ delight $\&$ full Perception of his hearers. [4th] Lastly one of them appeared mounted on a horse \& blowing a horn with a large Leathern bag affixed to his saddle by which was indicated 
that in the event of their discontinuing Hostilities $\&$ adopting a peaceful $\&$ orderly Demeanour Official Rank \& Station should be open to them \& that in time they might even aspire to the dignified \& confidential Employment one of Postman. ${ }^{22}$

While no records of Indigenous Tasmanian postmen have yet been found from this period, other elements of this sequence match various colonial practices and encounters, notably those connected with the Bruny Island Establishment founded in 1828 and likely occasions when Lieutenant Governors (including Arthur) met Indigenous Tasmanians. In sequence, Board C illustrated a narrative of assimilatory progress.

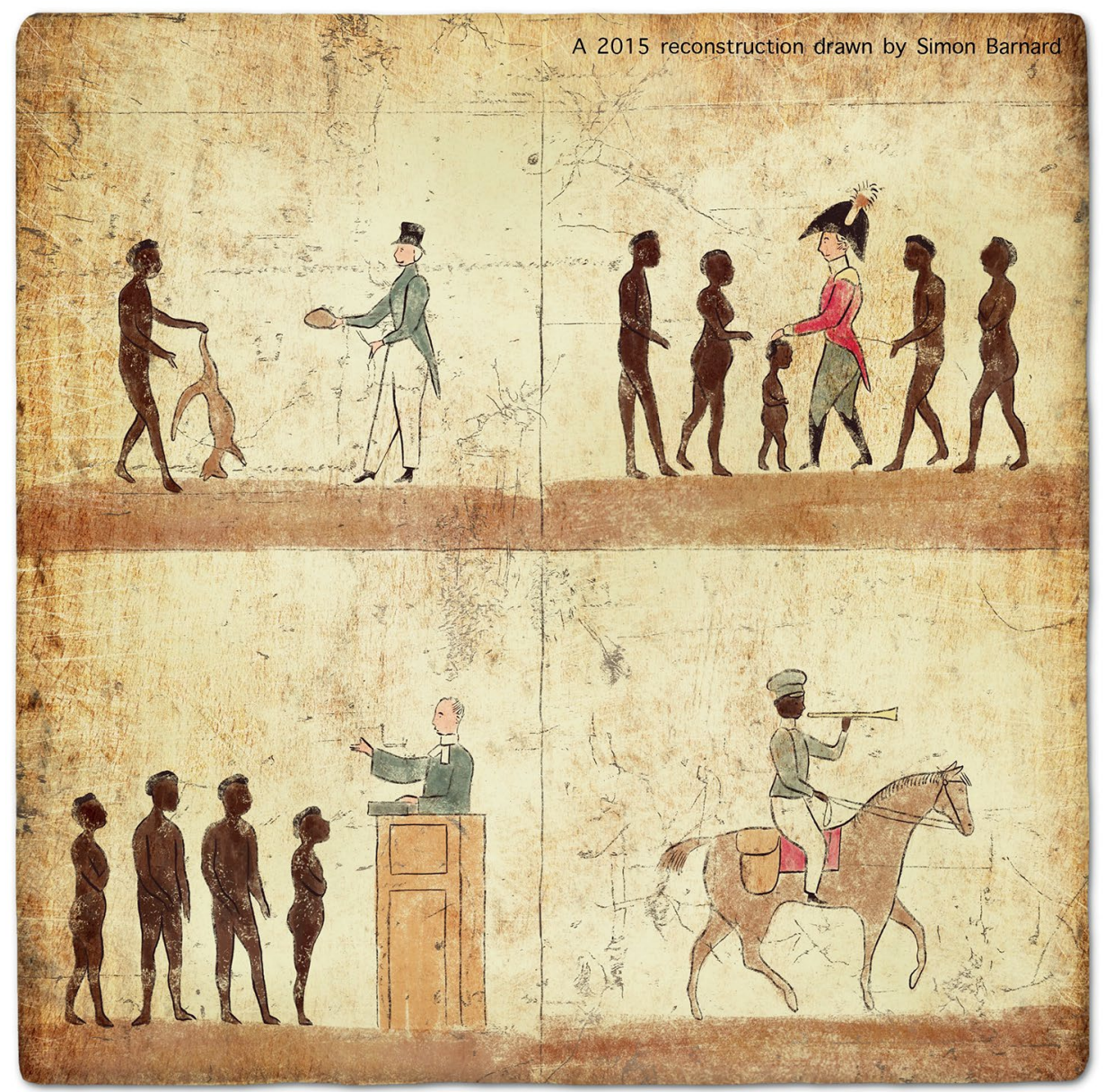

Figure 3: Board C, 2015. A reconstruction by Simon Barnard based on manuscript description.

Source: (C) Nicholas Dean Brodie and Kristyn Harman.

22 Allport MS: 3; Crowther 1926: 168. 
Significantly, both Boards B and C exhibit causal narratives stemming from Indigenous interactions with settlers. In both, unlike the surviving imagery of Board A, there is a clear narrative unity throughout the whole of each sequence. They are stories, with inceptions, causal links and conclusions. We argue that these likely reflect Frankland's two-part imagery focused on the effects of hostility and the effects of peace. Indigenous violence was met with force and punishment in Board B, and non-violent Indigenous encounter resulted in reward in Board C. We argue that these messages, blunt and binary, open avenues for a new approach to the iconographical frontier of conflict and conciliation in the Vandemonian War, and help broaden the scholarly discussion beyond the surviving iconography of Board A.

James Bonwick's The Last of the Tasmanians; or, The Black War of Van Diemen's Land of 1870 essentially developed the idea of picture boards as conciliatory in intent and a failure in practice, even while quoting materials that highlighted that there were multiple images beyond the surviving boards. He sarcastically characterised such attempts to communicate through picture as part of 'the expedition against the Aborigines on the principles of the Fine Arts'. ${ }^{23}$

Monographs addressing Tasmanian frontier relations written in the late twentieth century barely addressed the known imagery, despite sometimes using boards or their lithographic counterparts for illustrative purposes, leaving Bonwick's characterisation largely unquestioned. ${ }^{24}$ As recently as 2015, a survey history of Indigenous Tasmania characterised the whole endeavour as 'a ridiculous gesture'. ${ }^{25}$

More particular studies, ostensibly examining or contextualising the imagery of Board A, have reaffirmed such notions that the intended message of Board A was principally conciliatory and largely ineffectual. Julie Evans and Tessa Fluence see the boards in terms similar to Bonwick, treating Board A in parallel with Lieutenant Governor George Arthur's proclamation of martial law, and characterising the iconographical endeavour as a straightforward and unsuccessful attempt to resolve frontier conflict. ${ }^{26}$ Similarly, while she principally focused on a detailed reading of the materiality of these objects from an art historical perspective, Khadija von Zinnenburg Carroll reads the extant boards as having been crafted 'to impart ideas of equality between black and white, Aboriginal, convict and settler', a notion derived from earlier literature as much as from the imagery itself. ${ }^{27}$ Both articles reiterate the sense of action and failure. Evans and Fluence read in the imagery a type of official 'fantasy, as expressing official concerns about the legitimacy of settlement ...

23 Bonwick 1870: 83-84.

24 Ryan 1996: 97; Reynolds 1995; Clements 2014.

25 Johnson and McFarlane 2015: 135.

26 Evans and Fluence 2013: 18.

27 von Zinnenburg Carroll 2014: 73. 
even as dispossession was being enforced', and von Zinnenburg Carroll highlighted 'the falsity of the proclaimed equality in practice'. ${ }^{28}$ This contrast between Board A's nominal aspirations and their apparent failure, itself a nineteenth-century interpretation, has seemingly become the dominant historiographical message.

In contrast, other explorations of the aspirational elements of the Board A imagery and the materiality of frontier iconography have extended beyond the immediate narrative concerns of frontier conflict in 1820s and 1830s Van Diemen's Land. Desmond Manderson, for instance, argued that these 'pictures trace a movement from philosophy to politics to law', suggesting they conveyed strong assimilatory messages about the absorption of Indigenous people into colonial society, by which 'the people of Australia would all be subject to the law', derived from Britain, an argument about empire as well as equality. ${ }^{29}$ For Manderson, the boards were illustrative of wider conceptions about British colonial sovereignty.

Similarly focused on the global imperial context in which the boards were created, Penelope Edmonds compared the iconography of Board A with British, French and Spanish medals taken to the North American colonies, and anti-slavery tokens found in England, situating them in an imperial visual lexicon that extended across empires. Edmonds likened the depiction of the Lieutenant Governor's handshake with an Aboriginal chief portrayed on one of the panels to the 'humanitarian handshakes' found on these other artefacts, and saw this as reflecting a 'transference of iconography'. For Edmonds, the boards certainly have a pseudo-legal aspect, but they also have coded messages of empire and reflect cultural expressions of imperial humanitarianism. Edmonds has also pursued this iconographical resonance into modern times, exploring how Board A has become an icon for postcolonial artistic engagement with a troubled colonial past. ${ }^{30}$

Following the outward-looking work of Manderson and Edmonds, we argue that the imagery of the reconstructed Boards $\mathrm{B}$ and $\mathrm{C}$ also reflect wider national and international imperial concerns and colonial trends. Certainly, Boards B and C depict elements of 'the actual state of things' in colonial Van Diemen's Land, and belong to a precise moment in time. Their representation of military violence, Indigenous Tasmanians in custody, institutionalised instruction and cross-cultural Indigenous actors performing colonial services all neatly match actualities of the Vandemonian War of the 1820s and 1830s. ${ }^{31}$ These cannot be dismissed as figments of any colonial imagination, or as failed aspirations. Yet, there is more to be gained from these than a straightforward illustration of the Vandemonian situation. If the imagery of Board A has become a historiographical shorthand for missed opportunities, the

28 von Zinnenburg Carroll 2014: 90.

29 Manderson 2008: 226, 228-31.

30 Edmonds 2011; Edmonds 2016: 137-45.

31 Brodie 2017b. 
recovered iconography of Boards B and C can serve as stand-in narrative structures for reassessing wider elements of the whole frame of frontier conflict in colonial Australia. Ironically, their own lack of ambiguity makes them useful for addressing the ambiguities of Australia's troubled past.

The series of scenes on Board B, for instance, is certainly consistent with Indigenous experience from the early years of contact across the Australian colonies (which often continued well into the twentieth century). The first two frames depict Indigenous aggression towards and dispossession of settlers, easily understood now as resistance to colonisation, although at the time part of the logic behind strong colonial military action. The use of British soldiers described in the third frame was a regular feature of early colonial Australia, with British military regiments being regularly stationed in the colonies until $1870 . .^{32}$ As recently demonstrated in The Vandemonian War, the military regularly and actively campaigned against Aboriginal people. ${ }^{33}$ Frontier violence, however instigated, often spiralled into war.

Moreover, the iconography of captivity is deeply resonant of wide colonial experience. Aboriginal people were taken captive from the first year of settlement when in 1788 Governor Arthur Phillip issued instructions that an Aboriginal person be captured and restrained with a view to having the captive become an intermediary between the colonists and local Aboriginal people in Sydney. ${ }^{34}$ As the British incursion onto Aboriginal lands continued apace, the means through which they were restrained became increasingly sophisticated. Over time, at least 90 Aboriginal men were incorporated into the colonial convict system; in this and other contexts, Indigenous people were frequently restrained by handcuffs, leg irons and imprisonment. ${ }^{35}$ Later in the nineteenth century, groups of Aboriginal prisoners were chained together by the neck while being taken into captivity and sometimes throughout their sentences. ${ }^{36}$ Such practices continued into sufficiently recent times to be well attested by photographic records. ${ }^{37}$

Similarly, criminal trials like that depicted in Board B occurred, sometimes resulting in judicial execution. In Van Diemen's Land, there were four known judicial executions of Indigenous men during the 1820 s, most famously including the hanging of Musquito, a man transported from Sydney to Norfolk Island and then to Van Diemen's Land. ${ }^{38}$ Although the details of the cases are quite obscure, an Indigenous Tasmanian man was sentenced 'to labor in the gaol gang for the period of 12 months' in February 1818, and two were sentenced to three years transportation

32 Connor 2002: 10.

33 Brodie 2017b: 30-36.

34 Harman and Grant 2014: 159.

35 Harman 2012.

36 Harman and Grant 2014.

37 Lydon 2012.

38 Parry 2007; Harman 2012: 32-35. 
in November $1818 .{ }^{39}$ In the Port Phillip District in 1842, two Indigenous Tasmanians were sentenced to execution for murder and hanged. ${ }^{40}$ In Queensland, the execution of Dundalli in 1855 attracted significant public attention, not only for the justice meted out to a colonial enemy, but also for the botched job of the executioner. ${ }^{41}$

While ostensibly representing an alternate pathway for Indigenous people, the iconography of Board C is also consistent with colonial experience across Australia. Even by the late 1810s, a strong tradition had been established by the British colonists in New South Wales (which, until June 1825, included Van Diemen's Land) of suppressing Indigenous resistance and coercing proximate Indigenous peoples to acculturate to colonial economies. A prime example of this can be seen in Governor Lachlan Macquarie's 1816 instructions to his crack military regiments whom he ordered out on a punitive expedition against Aboriginal people in the Nepean, Hawkesbury and Grose river valleys. As well as urging them to take the bodies of Aborigines killed in action to be 'hanged up on trees in conspicuous situations, to strike the survivors with the greater terror', he instructed the soldiers to 'procure twelve boys and six girls ... for the Native Institution at Parramatta ... fine healthy good looking children ... aged between four and six years ${ }^{42}$ Once Indigenous people were sufficiently subdued, Macquarie aimed to 'civilise' them through introducing the adults to agricultural labour and the children to a Westernstyle education. Merete Borch has highlighted a similar duality in the instructions sent from the Secretaries of State in London to various Governors in the Australian colonies. For example, in July 1825 Governor Ralph Darling was told that he must 'promote religion and education amongst that Native Inhabitants of Our said Colony', yet was also instructed to 'oppose force by force, and to repel ... [Indigenous] aggressions'. ${ }^{43}$ Imperial aggression and Indigenous assimilation were contrasting and complementary notions.

The limited evidence of the Vandemonian 1810s reveals a considerable degree of intercultural intercourse, making this decade an important contextual referent for the boards that is often overlooked in discussion focused on the immediate wartime provenance. With many Indigenous children taken into service and employed, including those later punished for transgressing colonial laws, this period saw Indigenous people living and acting within colonial society in ways that were likely under-documented, and only hinted at by anomalous documentary moments. Official condemnation of colonists forcibly taking Indigenous children from their parents points to a difficult-to-trace phenomenon, but transgressions or accidents

\footnotetext{
39 Hobart Town Gazette and Southern Reporter, 7 February 1818: 2; 14 November 1818: 1.

40 Auty and Russell 2016.

41 Brodie 2015a: 87-89.

42 Macquarie, entry of 10 April 1816, 'The Governor's Diary \& Memorandum Book Commencing on and from Wednesday the 10th Day of April 1816 at Sydney in N.S.Wales', State Library of New South Wales, A773.

43 Borch 2004: 115.
} 
sometimes explicitly reveal it. When 'a black native boy named Paddy' was found killed in late 1817, he was identified as 'late stock-keeper to Mr. B. Reardon at Pitt Water' and his body subjected to a coronial inquest under suspicion of murder. ${ }^{44}$ In contrast to the repetitive mantra that Indigenous people were unequal before the law, there are certainly signs that some of them were, or were getting close in certain circumstances. The contingent factor was a behavioural suite, and the more assimilated to the colony, the less Indigenous they appear within the documentary record. Australian historiography has generally viewed Board A through the lens of a long history of race, but the immediate context of their production was more concerned with culture.

Yet that is not to deny the fact and import of institutionalisation, captured in the iconography of Board C. Across British colonies including Australia, Canada and New Zealand, the imperial government pursued what Andrew Armitage has characterised as 'policies of instruction', whereby indigenous people were schooled in educational institutions or on missions. ${ }^{45}$ Missionaries aimed to inculcate in indigenous people an agrarian and early industrial work ethic, and coerced them into wearing clothes and engaging in bodily regimes dictated by concerns for hygiene. Early missions and model villages frequently failed, with high death rates amongst the Indigenous inhabitants, as was the case at Bruny Island off the coast of Van Diemen's Land in the late 1820s and at Flinders Island in Bass Strait in the 1830s and 1840s. ${ }^{46}$ However, Australian colonists persisted in their attempts to house Indigenous people separately from the settler population while they underwent training considered requisite to becoming assimilated into the lower echelons of colonial society. Notions of Aboriginal people gradually becoming incorporated into colonial society, represented in Board C, highlight the potential evident in the actual historical context. Whether the child-servants of the $1810 \mathrm{~s}$, the once-famed case of the Aboriginal boy George Van Diemen who was educated in England, the prominent intercultural actors of the 1820s and 1830s like Kickerterpoller and Manalargenner, or the official government propagandising of a woman of Indigenous descent as a colonial female archetype, colonial integration was a real possibility in Van Diemen's Land, at least for some individuals. ${ }^{47}$

The iconography of these lost boards could have fitted within a wider colonial context than the particular moment of their original drafting, so they are useful both for exploring the Vandemonian situation and for illuminating a wider Australian one. We are confident these images reflect Frankland's original sketch conceptions

44 Hobart Town Gazette and Southern Reporter, 13 December 1817: 2; 20 December 1817: 2.

45 Armitage 1995: 33.

46 Plomely 1987.

47 Lawson 2013; Brodie 2014; Brodie 2015b. 
and likely also reflect the sort of sketching Frankland reportedly gifted to Eumarrah. These lost images thereby capture communicative attempts that were partly sincere, stemming from the endeavours of a noted advocate of restrained approaches to Indigenous Tasmanians, but also reflective of Arthur's tendency to propagandise about the humanitarianism of colonial policy. ${ }^{48}$ Textually situated between vague mention of an increase in hostilities and allusion to a proclamation, the description of Boards B and C in the Allport and Beattie MSS does not offer much chronological precision, but it is clear from these and all other sources that pictorial boards were only ever a minor element of the colonial frontier in Van Diemen's Land. Yet, by capturing an iconographical sequence of broader import, they may speak more effectively to our age than theirs.

However, the reverse was true for the author of 'The Aboriginal Natives of Van Diemen[']s Land', who likely wrote these accounts with a specific historical context in mind. These recollections, hinting at relative proximity to the events concerned, capture something of an understanding of events before a master narrative of Vandemonian contact and conflict was firmly established by prominent writers like Henry Melville from the mid-1830s and Bonwick in the 1870s. ${ }^{49}$ Lacking any specific mention of martial law (proclaimed in November 1828), not naming George Augustus Robinson in connection with expeditions to bring in the Aborigines (1829-34) and being hostile to Arthur in draft but not in clean copy, it is possible that this document was drafted very close to the period concerned, perhaps even as early as the 1830s, at a time when libelling Arthur was still a real prospect, encouraging the caution of the cleaner version of the text. ${ }^{50}$ These lost pictures offer little support to the standard historical characterisations of Robinson the 'Conciliator' or a deeply 'humanitarian' Lieutenant Governor Arthur. Rather than standing for 'what ifs', like the surviving Board A iconography of a benevolent and impartial government, the recovered images raise the question of what has been lost or even deliberately obscured from the iconography of the Australian past. Whether the uniformed Indigenous postman or soldiers firing on Indigenous Tasmanians, they represent images contrary to strong populist narratives of peaceful nationalism, and encourage continued historical investigation of the past's complex ambiguities.

Moreover, these are not the only lost images. In 1938, for instance, the demolition of the Empire Hotel in Hobart resulted in the rediscovery of an old wall painting long covered by wallpaper. To date, a sole newspaper description appears to be the only record of this painting:

48 Brodie 2017b.

49 Melville 1835; Brodie 2017a.

50 Hobart Town Courier, 8 November 1828: 1. 
Among the scenes depicted are a bushranger on horseback, an aborigines' corroboree, an aborigine being shot by a gun, a native devil chasing a kangaroo, and a prison warder. ${ }^{51}$

While the visual archive of frontier relations remains patchy, there certainly remains hope for further discoveries, even if some needs be reconstructed from text.

\section{References}

\section{Newspapers}

\section{Colonial Times}

Hobart Town Courier

Hobart Town Gazette and Southern Reporter

Mercury

Tasmanian and Austral-Asiatic Review

True Colonist

\section{Primary documents}

'Allport MS', Tasmanian Archives and Heritage Office, Allport Library and Museum Manuscripts, L8 Store, Box 2, Folder 1.

Tasmanian Archives and Heritage Office, LSD17/1/1: 23.

The Governor's Diary \& Memorandum Book Commencing on and from Wednesday the 10th Day of April 1816 at Sydney in N.S.Wales, State Library of New South Wales, A773.

\section{Published works}

Armitage, Andrew 1995, Comparing the Policy of Aboriginal Assimilation: Australia, Canada, and New Zealand, University of British Colombia Press, Vancouver.

Auty, Kate and Lynette Russell 2016, Hunt Them, Hang Them: 'The Tasmanians' in Port Phillip 1841-42, Justice Press, Melbourne.

Bonwick, James 1870, The Last of the Tasmanians; or, The Black War of Van Diemen's Land, Sampson Low, Son, \& Marston, London.

51 Mercury, 6 September 1938: 12 (emphasis added). 
Borch, Merete Falck 2004, Conciliation-Compulsion - Conversion: British Attitudes Towards Indigenous Peoples 1763-1814, Rodopi, Amsterdam.

Brodie, Nicholas Dean 2014, "From "Miss Dalrymple" to "Daring Dolly": A life of two historiographical episodes', Aboriginal History 38: 89-107.

_ 2015a, Kin: A Real People's History of Our Nation, Hardie Grant, Melbourne.

_ 2015b, “"He had been a faithful servant”: Henry Melville's lost manuscripts, Black Tom, and Aboriginal negotiations in Van Diemen's Land', Journal of Australian Colonial History 17: 45-64.

_ 2017a, “The last man left to tell the tale”: Challenging the conciliation master narrative in Van Diemen's Land', Australian Historical Studies 48(1): 87-103.

2017b, The Vandemonian War: The Secret History of Britain's Tasmanian Invasion, Hardie Grant, Melbourne.

Clements, Nicholas 2014, The Black War: Fear, Sex and Resistance in Tasmania, University of Queensland Press, St Lucia.

Connor, John 2002, Australian Frontier Wars, 1788-1838, University of New South Wales Press, Sydney.

Crowther, William L. 1926, 'Notes on the habits of the extinct Tasmanian race number II', Papers and Proceedings of the Royal Society of Tasmania: 165-69.

Davies, R.H. 1846, 'On the Aborigines of Van Diemen's Land', The Tasmanian Journal of Natural Science, Agriculture, Statistics, orc. 2(11): 409-20.

Edmonds, Penelope 2011, “Failing in every endeavour to conciliate”: Governor Arthur's proclamation boards to the Aborigines, Australian conciliation narratives and their transnational connections', Journal of Australian Studies 35(2): 201-18. doi.org/10.1080/14443058.2011.562227.

- 2016, Settler Colonialism and (Re)Conciliation: Frontier Violence, Affective Performances, and Imaginative Refoundings, Palgrave Macmillan, Basingstoke.

Evans, Julie and Tessa Fluence 2013, 'Securing the settler polity: Martial law and the Aboriginal peoples of Van Diemen's Land', Journal of Australian Colonial History 15: $1-22$.

Harman, Kristyn 2012, Aboriginal Convicts: Australian, Khoisan, and Māori Convicts, University of New South Wales Press, Sydney. 
Harman, Kristyn and Elizabeth Grant 2014, "'Impossible to detain without chains?" The use of restraints on Aboriginal people in policing and prisons', History Australia 11(3): 157-76.

Johnson, Murray and Ian McFarlane 2015, Van Diemen's Land: An Aboriginal History, University of New South Wales Press, Sydney.

Lawson, Zoe 2013, 'George Vandiemen: A Tasmanian Aborigine in Lancashire, England, (1822-27)', Journal of the Royal Australian Historical Society 99(2): 153-69.

Lydon, Jane 2012, The Flash of Recognition: Photography and the Emergence of Indigenous Rights, NewSouth Publishing, Sydney.

Manderson, Desmond 2008, 'Not yet: Aboriginal people and the deferral of the rule of law', Arena Journal 29/30: 219-72.

Melville, Henry 1835, The History of the Island of Van Diemen's Land, from the Year 1824 to 1835 , London.

Parry, Naomi 2007, “"Hanging no good for blackfellow”: Looking into the life of Musquito', in Transgressions: Critical Australian Indigenous Histories, Ingereth Macfarlane and Mark Hannah (eds), Aboriginal History Monograph 16, ANU E Press, Canberra: 153-76.

Plomely, N.J.B. (ed.) 1987, Weep in Silence: a History of the Flinders Island Aboriginal Settlement with the Flinders Island Journal of George Augustus Robinson, 1835-1839, Blubber Head Press, Hobart.

1991, Jorgen Jorgenson and the Aborigines of Van Diemen's Land, Blubberhead Press, Hobart.

Prinsep, Mrs Augustus 1833, The Journal of a Voyage from Calcutta to Van Diemen's Land: Comprising a Description of that Colony During a Six Month's Residence. From Original Letters Selected by Mrs. A. Prinsep, London.

Reynolds, Henry 1995, Fate of a Free People: A Radical Re-examination of the Tasmanian Wars, Penguin, Melbourne.

Ryan, Lyndall 1996, The Aboriginal Tasmanians, Allen \& Unwin, St Leonards.

von Zinnenburg Carroll, Khadija 2014, Art in the Time of Colony, Ashgate, Farnham. 
This text is taken from Aboriginal History, Volume 41, 2017, edited by Ingereth Macfarlane, published 2017 by ANU Press, The Australian National University, Canberra, Australia.

dx.doi.org/10.22459/AH.41.2017.01 